Article

\title{
Defect-Rich Nickel Nanoparticles Supported on SiC Derived from Silica Fume with Enhanced Catalytic Performance for CO Methanation
}

\author{
Qi Song ${ }^{1}$, Xingwu Zhai ${ }^{1,2}$, Feng Yu ${ }^{1, *} \mathbb{0}$, Jiangbing Li $^{1}$, Xin Ren ${ }^{1}$, Haiyang Zhang ${ }^{1} \mathbb{D}$, \\ Mingyuan Zhu ${ }^{1}$, Bin Dai ${ }^{1}$, Guixian $\mathrm{Ge}^{2, *}$ and Jinli Zhang ${ }^{1, *}$ \\ 1 Key Laboratory for Green Processing of Chemical Engineering of Xinjiang Bingtuan, School of Chemistry \\ and Chemical Engineering, Shihezi University, Shihezi 832003, China; ccsongqi@yeah.net (Q.S.); \\ zxw1725910806@163.com (X.Z.); ljbin@shzu.edu.cn (J.L.); renxin_shzu@163.com (X.R.); \\ zhy198722@163.com (H.Z.); zhuminyuan@shzu.edu.cn (M.Z.); db_tea@shzu.edu.cn (B.D.) \\ 2 Key Laboratory of Ecophysics and Department of Physics, College of Science, Shihezi University, \\ Xinjiang 832003, China \\ * Correspondence: yufeng05@mail.ipc.ac.cn (F.Y.); geguixian@126.com (G.G.); zhangjinli@tju.edu.cn (J.Z.); \\ Tel.: +86-993-205-7272 (F.Y. \& G.G. \& J.Z.); Fax: +86-993-205-7270 (F.Y. \& G.G. \& J.Z.)
}

Received: 23 January 2019; Accepted: 20 March 2019; Published: 24 March 2019

\begin{abstract}
With the increased demands of environmental protection, recycling/utilization of industrial byproducts has attracted much attention from both industry and academic communities. In this work, silicon carbide ( $\mathrm{SiC}$ ) was successfully synthesized from industrial waste silica fume (SF) during metallic silicon production. Following this, Ni nanoparticles with many defects were supported on the as-obtained $\mathrm{SiC}$ by conventional impregnation method. The results showed that defect-rich $\mathrm{Ni}$ nanoparticles were dispersed onto the surface of $\mathrm{SiC}$. The as-obtained Ni/SF-SiC exhibited an enhanced metal-support interaction between $\mathrm{Ni}$ and $\mathrm{SiC}$. Furthermore, the density functional theory (DFT) calculations showed that the $\mathrm{H}_{2}$ and $\mathrm{CO}$ adsorption energy on $\mathrm{Ni}$ vacancy $\left(\mathrm{V}_{\mathrm{Ni}}\right)$ sites of $\mathrm{Ni} / \mathrm{SF}-\mathrm{SiC}$ were 1.84 and $4.88 \mathrm{eV}$, respectively. Finally, the Ni/SF-SiC performed high catalytic activity with $\mathrm{CO}$ conversion of $99.1 \%$ and $\mathrm{CH}_{4}$ selectivity of $85.7 \%$ at $350{ }^{\circ} \mathrm{C}, 0.1 \mathrm{MPa}$ and a gas hourly space velocity (GHSV) of $18,000 \mathrm{~mL} \cdot \mathrm{g}^{-1} \cdot \mathrm{h}^{-1}$. Moreover, Ni/SF-SiC processed good catalytic stability in the $50 \mathrm{~h}$ continuous reaction.
\end{abstract}

Keywords: defect-rich catalyst; silicon carbide; silica fume; synthetic natural gas; carbon monoxide methanation

\section{Introduction}

Metallic silicon is also known as industrial silicon or crystalline silicon and is usually produced by reducing silicon dioxide from carbon in an electric furnace. It is mainly used as an additive for non-ferrous alloys or as a raw material for the production of semiconductor silicon and silicone. The amount of metallic silicon production capacity in China was 7.5 million tons in 2018. With growing demand for metallic silicon, the related industries have been burgeoning. It is inevitable that a large amount of silica fume is derived from metallic production (about 0.3 tons of silicon fume/ton of products). However, handling the problems of silica fume properly is not easy or smooth during the production. There is a large quantity of silica fume deserted in industrial disposal, which not only brings about resource wastage, but also results in serious pollution from the dust and powder [1,2].

Silica fume has excellent properties of pozzolanic, which is mainly used in concrete and refractory materials [3]. Recently, silica fume was widely used as support for the reaction of dry reforming of methane [4], or as silica source of producing mesoporous silicate materials (MCM-41, SAB-15, zeolite 
SSZ-13, etc.) and to synthesize $\mathrm{SiC} / \mathrm{Si}_{3} \mathrm{~N}_{4}$ powder [5-7]. A porous silicon nano-cluster was synthesized by using waste silica fume from the metallurgical grade silicon industry (MG-Si). This material was used in lithium ion batteries, showing excellent electrochemical properties [8]. However, further utilization of silica fume has seldom been realized, and therefore it is necessary to develop a new technique to produce materials beneficial to the economy and environment.

The present study concentrates on the synthesis of silicon carbide ceramic material, and then on successfully preparing a Ni/SF-SiC catalyst, using silica fume as the raw material. Considering that silica fume contains more than $97 \%$ of $\mathrm{SiO}_{2}$ and a small amount of $\mathrm{SiC}$, silica fume has naturally become an ideal raw material for $\mathrm{SiC}$ production, as well as for its associated decrease of production cost. In recent years, with increased demand on natural gas, and the aspiration to strengthen national energy security and increase energy efficiency, the production of synthetic natural gas (SNG) from coal or biomass has aroused widespread concern [9-13]. Being a good potential material, $\mathrm{SiC}$ has extensive applications in many fields, especially working in harsh environments as a support due to its excellent properties including high heat conductivity, thermal stability, mechanical strength, and chemical inertness [14-19]. SiC has been applied to various reactions, including methane reforming and combustion, Fischer-Tropsch synthesis, isomerization and dehydrogenation, among others [20,21]. Therefore, making full use of the waste generated during industrial production not only achieves the maximum use of resources, but also makes a great contribution to the protection of the environment. Additionally, a Ni/SF-SiC catalyst with metal defects is a promising approach to enhance the catalytic activity of methanation.

\section{Results and Discussion}

The reactivity of $\mathrm{Ni} / \mathrm{SF}-\mathrm{SiO}_{2}$ and $\mathrm{Ni} / \mathrm{SF}-\mathrm{SiC}$ catalysts was tested at $250-550{ }^{\circ} \mathrm{C}$ at a GHSV $18,000 \mathrm{~mL} \cdot \mathrm{g}^{-1} \cdot \mathrm{h}^{-1}$ and $0.1 \mathrm{MPa}$, as shown in Figure 1. With increasing test temperature, the catalytic performances of these catalysts were improved. There are some differences as the reaction temperature raised to $250{ }^{\circ} \mathrm{C}$ : The $\mathrm{CH}_{4}$ selectivity of Ni/SF-SiC was $84.1 \%$, while $\mathrm{Ni} / \mathrm{SF}-\mathrm{SiO}_{2}$ was $0 \%$. At $350{ }^{\circ} \mathrm{C}$, the $\mathrm{CO}$ conversion of the catalyst $\mathrm{Ni} / \mathrm{SF}-\mathrm{SiC}$ achieved $99.1 \%$, and the $\mathrm{CO}$ conversion of the catalyst $\mathrm{Ni} / \mathrm{SF}-\mathrm{SiO}_{2}$ was only $89.8 \%$. Furthermore, the $\mathrm{CH}_{4}$ selectivity and yield for Ni/SF-SiC catalyst was $85.7 \%$ and $84.9 \%$ at $350{ }^{\circ} \mathrm{C}$, respectively, but for $\mathrm{Ni} / \mathrm{SF}-\mathrm{SiO}_{2}$ catalyst, the $\mathrm{CH}_{4}$ selectivity and yield was only $75.0 \%$ and $67.4 \%$, respectively. In addition, we researched the $50 \mathrm{~h}$ stability test for $\mathrm{Ni} / \mathrm{SF}-\mathrm{SiO}_{2}$ and Ni/SF-SiC at $350{ }^{\circ} \mathrm{C}$, and the results are presented in Figure 1c. The reactivity and stability of $\mathrm{Ni} / \mathrm{SF}-\mathrm{SiC}$ are much better than $\mathrm{Ni} / \mathrm{SF}_{-} \mathrm{SiO}_{2}$ [22]. When the temperature went beyond $400{ }^{\circ} \mathrm{C}$, these catalysts decreased slightly in catalytic activity, because the catalyst $\mathrm{Ni} / \mathrm{SF}-\mathrm{SiC}$ was limited by thermodynamics in the strongly exothermic reaction. In a high temperature reaction, it is easy for the $\mathrm{Ni} / \mathrm{SF}-\mathrm{SiO}_{2}$ catalyst to be sintered and carbon deposited, which results in the decrease of catalyst activity [23-25]. In Table 1, we compared the CO catalytic performances of different catalysts, and the catalyst $\mathrm{Ni} / \mathrm{SF}-\mathrm{SiC}$ exhibited excellent performance.
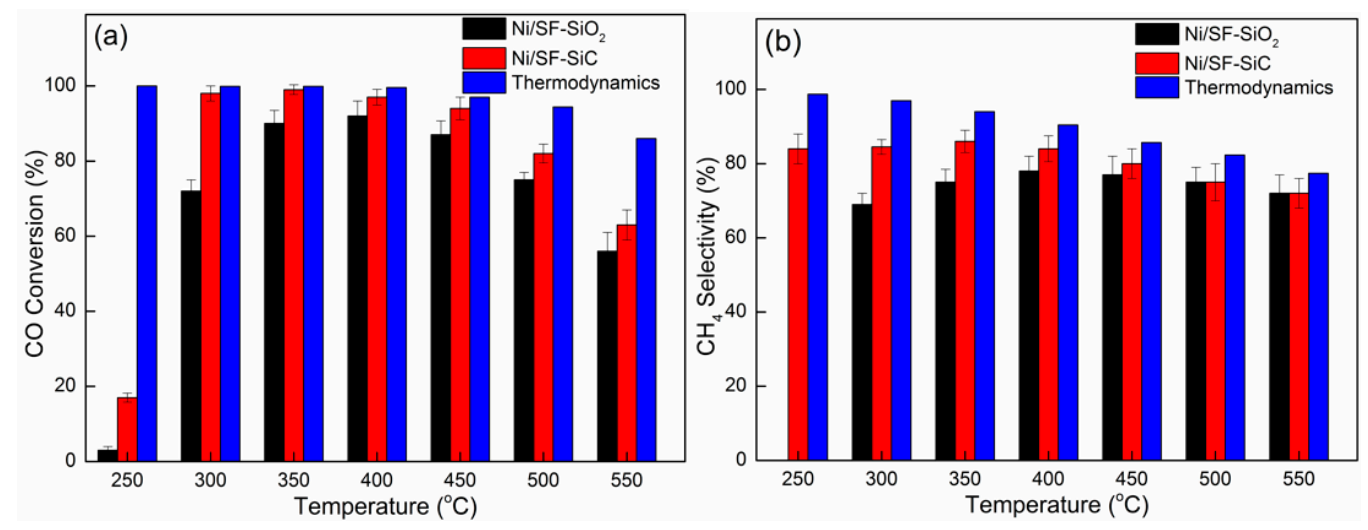

Figure 1. Cont. 

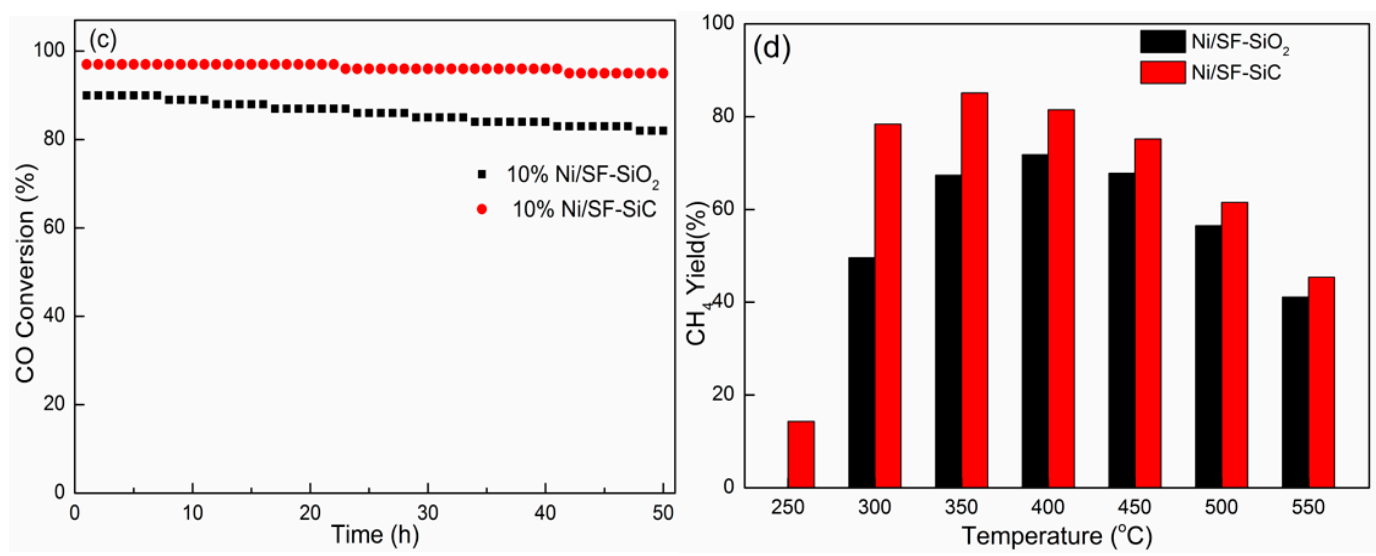

Figure 1. Catalytic performances of catalysts in $\mathrm{CO}$ methanation under different reaction temperatures at $0.1 \mathrm{MPa}$ and GHSV of $18,000 \mathrm{~mL} \cdot \mathrm{g}^{-1} \cdot \mathrm{h}^{-1}$ : (a) CO Conversion, (b) $\mathrm{CH}_{4}$ Selectivity and (d) $\mathrm{CH}_{4}$ yield of $\mathrm{Ni} / \mathrm{SF}-\mathrm{SiO}_{2}$ and $\mathrm{Ni} / \mathrm{SF}-\mathrm{SiC}$; (c) long-time stability test of $\mathrm{Ni} / \mathrm{SF}-\mathrm{SiO}_{2}$ and $\mathrm{Ni} / \mathrm{SF}-\mathrm{SiC}$ at $350{ }^{\circ} \mathrm{C}$, $0.1 \mathrm{MPa}$ and GHSV of $18000 \mathrm{~mL} \cdot \mathrm{g}^{-1} \cdot \mathrm{h}^{-1}$.

The detailed information for components of the supports and catalysts were investigated by X-ray diffraction (XRD). In Figure 2, the diffraction peaks of SF-SiC and Ni/SF-SiC at $34.8^{\circ}, 35.72^{\circ}$, $38.23^{\circ}, 41.50^{\circ}, 49.77^{\circ}, 60.15^{\circ}, 65.80^{\circ}, 71.96^{\circ}, 73.59^{\circ}$ and $75.65^{\circ}$ are related to distinct peaks of $\mathrm{SiC}$ (JCPDS 29-1131) [26]. In addition, $\mathrm{SiC}$ characteristic peaks at $2 \theta$ of $35.72^{\circ}, 60.15^{\circ}$ and $71.96^{\circ}$ of the support, fresh and used Ni/SF-SiO ${ }_{2}$, were also clearly observed. Furthermore, the diffraction peak at $21.98^{\circ}$ was attached to $\mathrm{SiO}_{2}$ (JCPDS 29-0085). For the above catalysts, the diffraction peaks at $44.50^{\circ}$, $51.84^{\circ}$ and $76.37^{\circ}$ belonged to face centered cubic Ni (JCPDS 04-0850) [27]. In the Ni/SF-SiC catalyst, the intensity of $\mathrm{Ni}$ diffraction peak was slightly weaker than the Ni/SF-SiC catalyst, revealing the higher dispersion of $\mathrm{Ni}$ species over the Ni/SF-SiC catalyst surfaces [28]. The mean size estimation of Ni crystallites is discussed by the Scherrer equation, and the results are shown in Table $2[29,30]$. Compared with the $\mathrm{Ni} / \mathrm{SF}-\mathrm{SiO}_{2}$ catalyst, the crystallite size of $\mathrm{Ni}$ in the Ni/SF-SiC catalyst did not change before and after the reaction, which shows the Ni/SF-SiC catalysts possesses an excellent anti-sintering property. However, in the used $\mathrm{Ni} / \mathrm{SF}-\mathrm{SiO}_{2}$ catalyst, the crystallite size of $\mathrm{Ni}$ particle was larger than the freshly reduced $\mathrm{Ni} / \mathrm{SF}-\mathrm{SiO}_{2}$ catalyst; this phenomenon can be ascribed mainly to the aggregation of $\mathrm{Ni}$ species of $\mathrm{Ni} / \mathrm{SF}-\mathrm{SiO}_{2}$, which further indicates that the $\mathrm{Ni} / \mathrm{SF}-\mathrm{SiC}$ catalyst has better anti-sintering and anti-aggregation properties than $\mathrm{Ni} / \mathrm{SF}-\mathrm{SiO}_{2}$ catalyst [21].

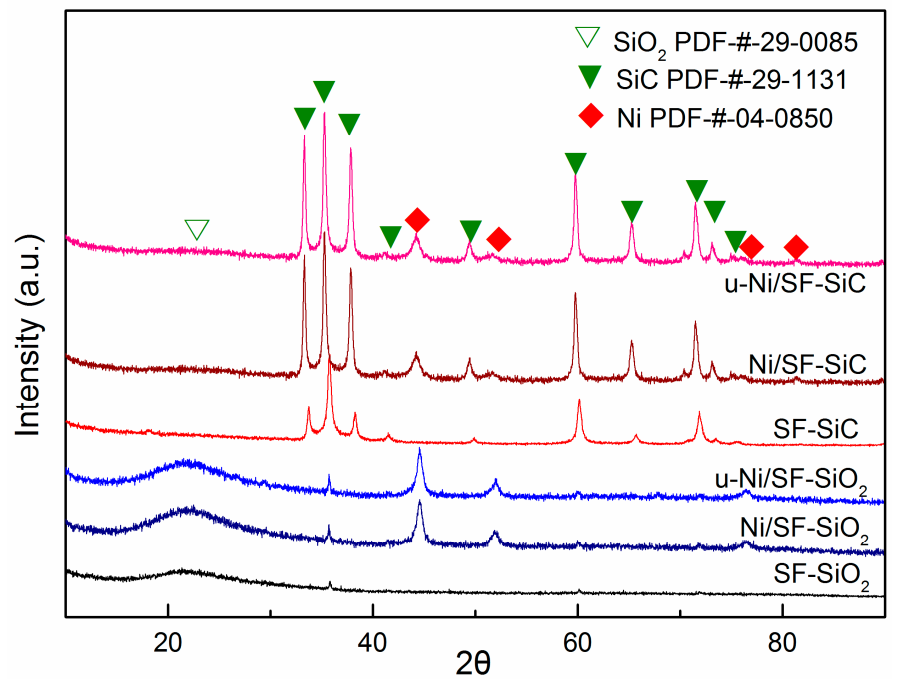

Figure 2. Wide-angle XRD patterns of the support and the catalysts $\mathrm{SF}_{-} \mathrm{SiO}_{2}, \mathrm{Ni} / \mathrm{SF}-\mathrm{SiO}{ }_{2}, \mathrm{u}-\mathrm{Ni} / \mathrm{SF}-\mathrm{SiO}_{2}$, SF-SiC, Ni/SF-SiC, u-Ni/SF-SiC. 
Table 1. The comparison of catalytic performance in different works.

\begin{tabular}{|c|c|c|c|c|c|c|c|c|}
\hline Catalysts & Raw Material & $\begin{array}{c}\text { Optimum } \\
\text { Temperature } \\
\left({ }^{\circ} \mathrm{C}\right)\end{array}$ & $\begin{array}{c}\text { Pressure } \\
(\mathrm{MPa})\end{array}$ & $\begin{array}{c}\text { Space } \\
\text { Velocity } \\
\left(\mathrm{mL} \cdot \mathrm{g}^{-1} \cdot \mathrm{h}^{-1}\right)\end{array}$ & $\begin{array}{c}\text { CO } \\
\text { Conversion } \\
(\%)\end{array}$ & $\begin{array}{c}\mathrm{CH}_{4} \\
\text { Selectivity } \\
(\%)\end{array}$ & $\begin{array}{c}\text { Space-Time } \\
\text { Yield } \mathrm{CH}_{4} \\
\left(\mathrm{~mL} \cdot \mathrm{g}^{-1} \cdot \mathrm{h}^{-1}\right)\end{array}$ & Refs. \\
\hline $7 \% \mathrm{Ce}-10 \% \mathrm{Ni} / \mathrm{SiC}$ & $\mathrm{SiO}_{2}$ & 600 & 1 & 60,000 & 95 & 85 & 41,182 & [28] \\
\hline $10 \% \mathrm{Ni} / \mathrm{SiO}_{2}$ & $\mathrm{SiO}_{2}$ & 420 & - & 60,000 & 95.8 & 75.2 & 43,225 & [29] \\
\hline $10 \% \mathrm{NiO} / \mathrm{VMT}-\mathrm{LDO}$ & VMT-waste water & 400 & 1.5 & 20,000 & 87.88 & 89.97 & 15,813 & [9] \\
\hline 10\%Ni/SBA-15(ET) & Tetraethylorthosilicate & 400 & 0.3 & 15,000 & 100 & - & - & [30] \\
\hline $10 \% \mathrm{NiO} / \mathrm{Al}_{2} \mathrm{O}_{3}$ & $\mathrm{Al}_{2} \mathrm{O}_{3}$ & 350 & 0.1 & 120,000 & 91.2 & 75 & 82,080 & [32] \\
\hline
\end{tabular}

Table 2. Physical and chemical properties of the catalysts and supports.

\begin{tabular}{|c|c|c|c|c|c|c|c|}
\hline Samples & $\mathrm{S}_{\text {BET }}\left(\mathrm{m}^{2} / \mathrm{g}\right)^{1}$ & $\mathrm{Vp}\left(\mathrm{cm}^{3} / \mathrm{g}\right)^{2}$ & $\mathrm{Vp}\left(\mathrm{cm}^{3} / \mathrm{g}\right)^{2 *}$ & $\mathrm{Dp}(\mathrm{nm})^{2}$ & $\mathrm{Dp}(\mathrm{nm})^{2 *}$ & $\mathrm{D}_{\mathrm{Ni}}(\mathrm{nm})^{3}$ & $\mathrm{D}_{\mathrm{Ni}}(\mathrm{nm})^{4}$ \\
\hline $\mathrm{SF}-\mathrm{SiO}_{2}$ & 18.6 & 0.10 & 0.10 & 36.4 & 39.6 & - & - \\
\hline $\mathrm{Ni} / \mathrm{SF}-\mathrm{SiO}_{2}$ & 21.0 & 0.13 & 0.13 & 34.1 & 36.9 & 12.6 & 15.6 \\
\hline $\mathrm{u}-\mathrm{Ni} / \mathrm{SF}-\mathrm{SiO}_{2}$ & 21.2 & 0.13 & 0.13 & 31.3 & 33.0 & 18.9 & 17.7 \\
\hline SF-SiC & 45.2 & 0.20 & 0.20 & 19.9 & 19.1 & - & - \\
\hline $\mathrm{Ni} / \mathrm{SF}-\mathrm{SiC}$ & 36.7 & 0.18 & 0.18 & 22.3 & 22.1 & 10.9 & 16.9 \\
\hline u-Ni/SF-SiC & 42.2 & 0.18 & 0.18 & 21.3 & 20.9 & 12.3 & 16.9 \\
\hline
\end{tabular}

${ }^{1}$ Surface area derived from the Brunauer-Ennett-Teller (BET) equation. ${ }^{2}$ Desorption average pore volume and pore diameter derived from Barret-Joyner-Halenda $(\mathrm{BJH})$ method. ${ }^{2 *}$ Adsorption average pore volume and pore diameter derived from Barret-Joyner-Halenda (BJH) method. ${ }^{3}$ Calculated according to equation $\mathrm{D}_{\mathrm{Ni}}=\sum_{\mathrm{Ni}} \mathrm{D}_{\mathrm{i}}{ }^{3} / \sum_{\mathrm{Ni}} \mathrm{D}_{\mathrm{i}}{ }^{2}$ from HRTEM. ${ }^{4}$ Estimated from the XRD diffraction peak $(2 \theta=44.6)$ using the Scherrer equation as follows: $\mathrm{L}=0.9 \lambda_{\mathrm{k} \alpha 1} / \mathrm{B}_{(2 \theta)} \cos \theta_{\max }$ where $\mathrm{L}$ denotes the average particle size, 0.9 is the value in radians when $\mathrm{B}_{(2 \theta)}$ is the full width at half maximum (FWHM) of the peak, $\mathrm{k} \alpha 1$ is the wavelength of the X-ray radiation $(0.15406 \mathrm{~nm})$, and max is the angular position at the (1 111 ) peak maximum of $\mathrm{Ni}$.

From the SEM and HRTEM images, the fine spherical particles of silica fume could clearly be observed, as shown in Figure 3a,c. The images of the as-prepared SF-SiC powder are shown in Figure $3 b, d$, which reveal that $\mathrm{SF}-\mathrm{SiC}$ has porous and irregular particle morphologies. This is due to the large amount of heat released by magnesium thermal reaction, which seriously destroyed the morphology and structure of $\mathrm{SF}_{-} \mathrm{SiO}_{2}$. At the same time, the thermal effect greatly improved the values of specific surface areas and average pore volumes of SF-SiC, and such results can also be seen in Table 2. The larger specific areas of SF-SiC support may provide more attachment sites for the active component. Compared with the amorphous silica fume (Figure 3e), the HRTEM image (Figure 3f) shows that the SF-SiC has good crystallinity with distinct lattice fringes of $0.251 \mathrm{~nm}$ and $0.262 \mathrm{~nm}$ corresponding to the $\mathrm{SiC}(102)$ and (101) planes, respectively.

In order to analyze and evaluate the distribution of Ni particles in the above catalysts, the SEM and HRTEM images of the freshly reduced catalysts $\mathrm{Ni} / \mathrm{SF}-\mathrm{SiO}_{2}$ and $\mathrm{Ni} / \mathrm{SF}-\mathrm{SiC}$ are shown in Figure 4 . It can be clearly observed that small $\mathrm{Ni}$ particles were dispersed over the $\mathrm{Ni} / \mathrm{SF}-\mathrm{SiO}_{2}$ surface with aggregating phenomenon, as shown in Figure 4a. At the same time, the Ni particles can be clearly observed, which was caused by different contrast values in the images of Figure 4c,d. In comparison with $\mathrm{Ni} / \mathrm{SF}-\mathrm{SiO}_{2}$ (mean sizes of Ni particles, $12.6 \mathrm{~nm}$ ), the smaller Ni particles uniformly distributed in $\mathrm{Ni} / \mathrm{SF}-\mathrm{SiC}$ (mean sizes of Ni particles, $10.9 \mathrm{~nm}$ ), it is obvious that Ni particles have better dispersion in $\mathrm{Ni} / \mathrm{SF}-\mathrm{SiC}$ than $\mathrm{Ni} / \mathrm{SF}_{-} \mathrm{SiO}_{2}[21,33,34]$. The smaller $\mathrm{Ni}$ nanoparticles on $\mathrm{Ni} / \mathrm{SF}-\mathrm{SiC}$ could be attached to the stronger metal support interaction between $\mathrm{Ni}$ and SF-SiC, compared with $\mathrm{Ni} / \mathrm{SF}-\mathrm{SiO}_{2}$ [35]. Moreover, the smaller Ni particles are beneficial for a high methanation rate. From Figure $4 \mathrm{e}, \mathrm{f}$, the lattice spacing of ca. $0.176 \mathrm{~nm}$ and $0.203 \mathrm{~nm}$ correspond to the Ni (200) and (111) plane. In Figure 4f, many distortions can be clearly observed, which were related to the novel defects-rich structure. Meanwhile, the defect-rich structure was also present in $\mathrm{Ni} / \mathrm{SF}_{-} \mathrm{SiO}_{2}$ catalysts (Figure 4e) [36]. The HRTEM element mapping of $\mathrm{Ni} / \mathrm{SF}-\mathrm{SiO}_{2}$ and $\mathrm{Ni} / \mathrm{SF}-\mathrm{SiC}$ are shown in Figure 4 and it can be clearly observed that the larger Ni particles were dispersed on spherical morphology of $\mathrm{SF}_{-} \mathrm{SiO}_{2}$ surface, but the smaller $\mathrm{Ni}$ nanoparticles were highly dispersed on the support of SF-SiC [37]. 

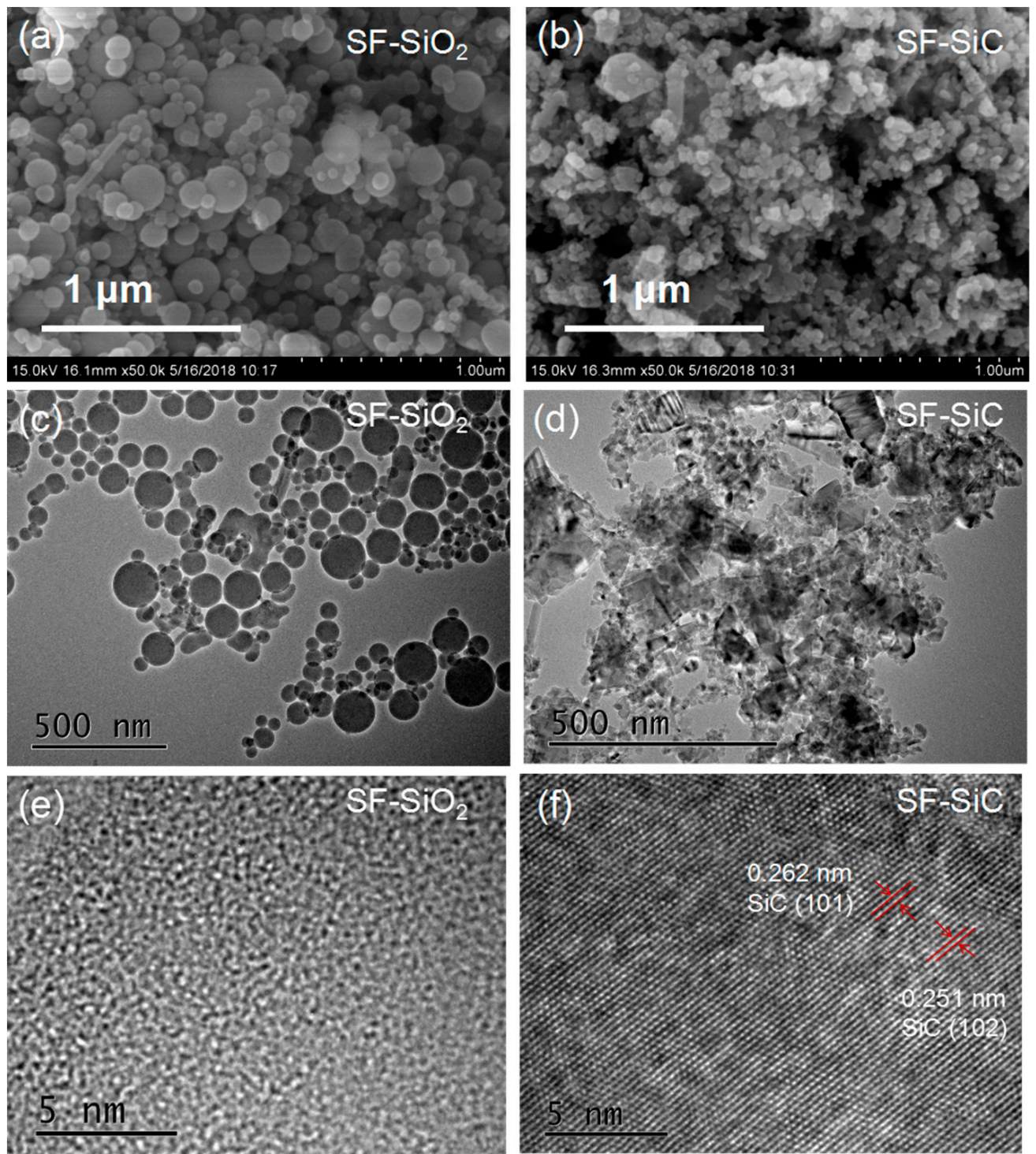

Figure 3. SEM images of the samples: (a) $\mathrm{SF}_{-} \mathrm{SiO}_{2}$, (b) SF-SiC; HRTEM images of samples: (c,e) $\mathrm{SF}_{-} \mathrm{SiO}_{2}$; (d,f) SF-SiC.

The $\mathrm{N}_{2}$ adsorption-desorption was employed to measure the physical properties of the catalysts, as shown in Table 2. Compared with $\mathrm{SF}_{-} \mathrm{SiO}_{2}$-support catalysts, the SF-SiC supporting catalysts show higher specific surface areas and pore volume, which should be attached to the influence of molten salt-mediated magnesiothermic reduction [14]. Figure 3 shows that the surface of $\mathrm{SiO}_{2}$ was smooth with a few pores. However, after loading Ni species, the specific surface areas and pore volume of $\mathrm{Ni} / \mathrm{SF}-\mathrm{SiO}_{2}$ were obviously increased, which may be attributed to the rough surface of $\mathrm{Ni} / \mathrm{SF}-\mathrm{SiO}_{2}$ produced by Ni particles loading and many holes produced among these Ni particles. However, the Ni precursors were introduced to the interior pore walls and the pore of the support was blocked, which explained that the specific surface areas and pore volume of Ni/SF-SiC were decreased. At the same time, this phenomenon also caused a slight change of average pore diameter in the $\mathrm{Ni} / \mathrm{SF}-\mathrm{SiO}_{2}$ and $\mathrm{Ni} / \mathrm{SF}-\mathrm{SiC}$ catalysts [38]. 

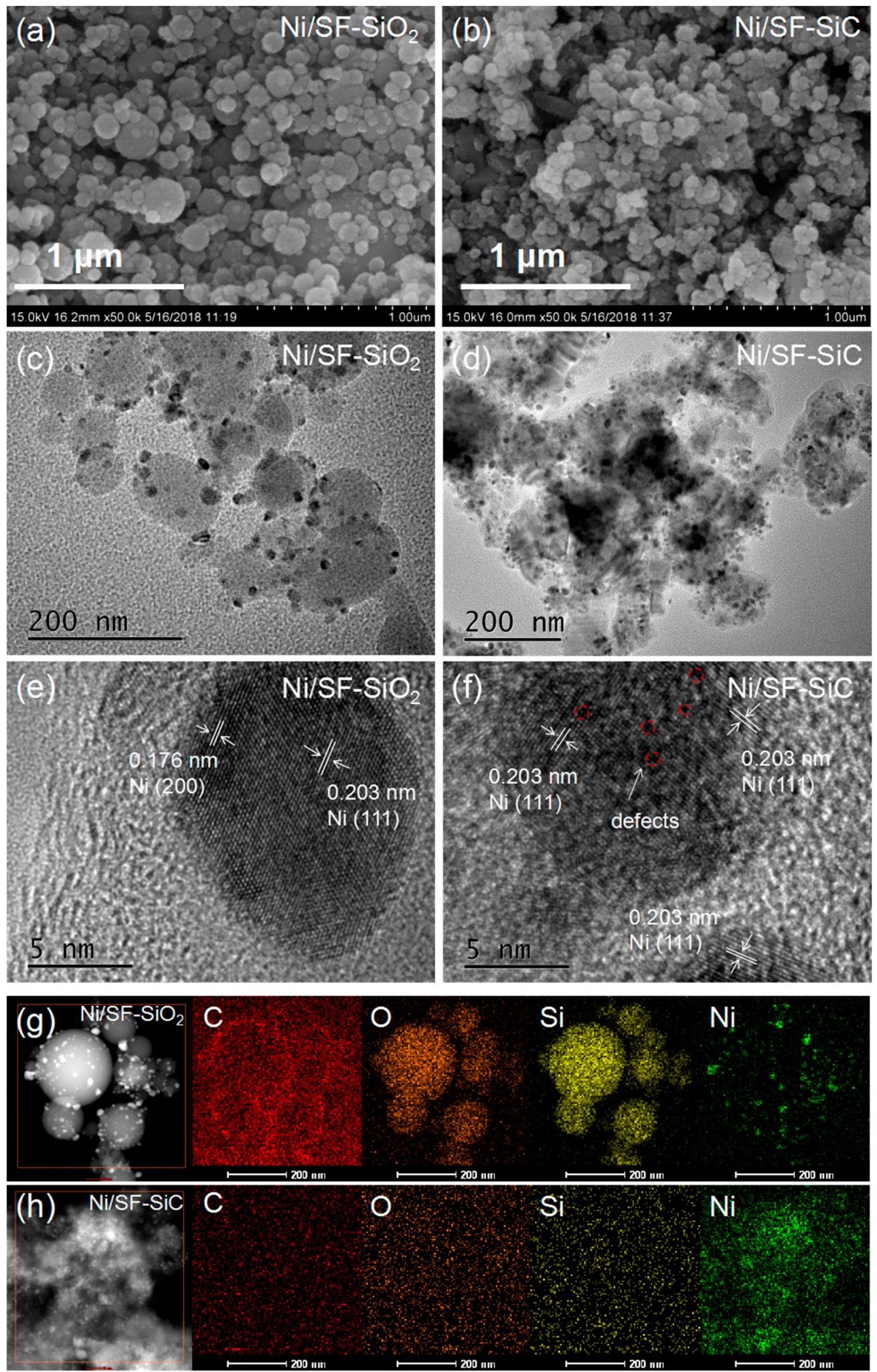

Figure 4. SEM images of the samples: (a) Ni/SF-SiO 2 , (b) Ni/SF-SiC. HRTEM images of the reduced catalysts: (c,e) Ni/SF-SiO 2 and (d,f) Ni/SF-SiC. HRTEM elemental mapping images of $\mathrm{C}, \mathrm{O}, \mathrm{Si}$ and $\mathrm{Ni}$ of $(\mathrm{g}) \mathrm{Ni} / \mathrm{SF}-\mathrm{SiO}_{2}$ and (h) Ni/SF-SiC.

In Figure 5, based on the temperature programmed reduction (TPR) results, the curves of the two catalysts are similar. There was a strong peak with a shoulder peak in the $\mathrm{NiO} / \mathrm{SF}-\mathrm{SiO}_{2}$, 
the previous peak in the low temperature region was related to $\alpha$-type $\mathrm{NiO}$ species and played a dominant role in nickel oxide species, which were assigned to the weaker interaction in $\mathrm{Ni} / \mathrm{SF}-\mathrm{SiO}_{2}$ [31], and another peak was corresponded to $\beta$-type $\mathrm{NiO}$ species, which had a stronger interaction with the $\mathrm{SF}-\mathrm{SiO}_{2}[39,40]$. In comparison with the $\mathrm{NiO} / \mathrm{SF}-\mathrm{SiO}_{2}$ catalyst, the spectrum of the $\mathrm{NiO} / \mathrm{SF}-\mathrm{SiC}$ also had a broader peak, and the peak at a higher temperature could be associated with the reduction of nickel silicate, implying the enhanced interaction between $\mathrm{NiO}$ and the support of SF-SiC $[33,41]$. In addition, the overlapping peaks of TPR profiles were fitted by the Gaussian function and classified into four peaks; the peak positions and the quantitative results of relative content are shown in Table 3. It can be seen that there were four peaks in the NiO/SF-SiC. However, there were just three reduction peaks in $\mathrm{NiO} / \mathrm{SF}-\mathrm{SiO}_{2}$, suggesting that the interaction between $\mathrm{NiO}$ and support was weaker. Compared with $\mathrm{NiO} / \mathrm{SF}_{-} \mathrm{SiO}_{2}$, the fraction of $\beta$-type $\mathrm{NiO}$ species of $\mathrm{NiO} / \mathrm{SF}-\mathrm{SiC}$ was larger, implying a stronger interaction between $\mathrm{NiO}$ and support. By comparing the $\mathrm{H}_{2}$ consumption of the reduction peaks for the two catalysts, it can be found that more $\mathrm{H}_{2}$ was consumed in the $\mathrm{NiO} / \mathrm{SF}-\mathrm{SiC}$ catalyst.

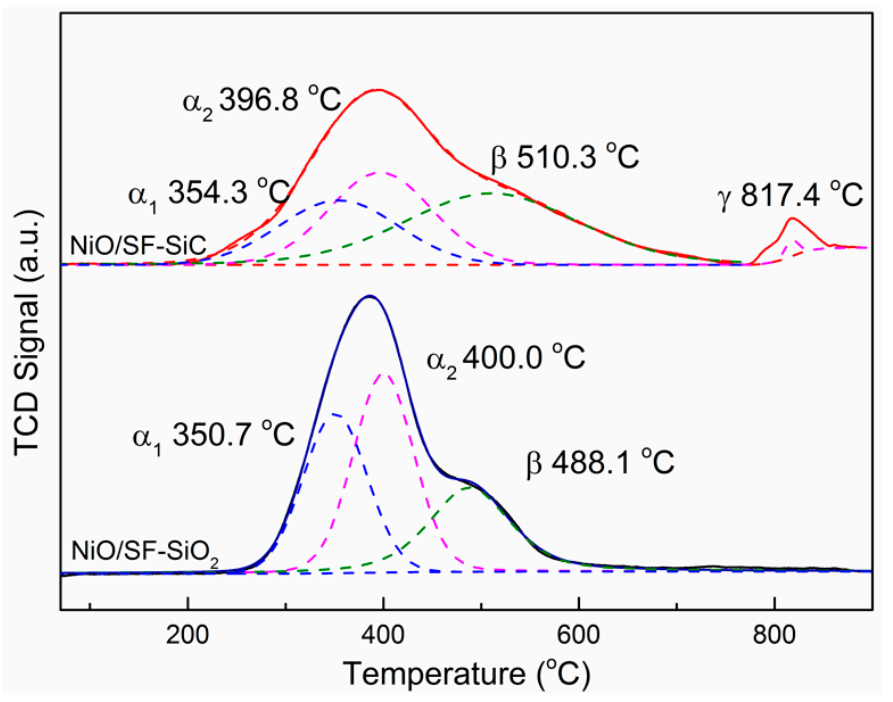

Figure 5. $\mathrm{H}_{2}$-TPR profiles of the as-prepared $\mathrm{NiO} / \mathrm{SF}-\mathrm{SiO}_{2}$ and $\mathrm{NiO} / \mathrm{SF}-\mathrm{SiC}$ catalysts.

Table 3. Gaussian fitting analysis of $\mathrm{H}_{2}$ temperature programmed reduction $\left(\mathrm{H}_{2}-\mathrm{TPR}\right)$ patterns of different catalysts.

\begin{tabular}{|c|c|c|c|c|c|c|c|c|c|c|c|c|}
\hline \multirow{2}{*}{ Samples } & \multicolumn{4}{|c|}{ Reduction Temperature $\left({ }^{\circ} \mathrm{C}\right)$} & \multicolumn{4}{|c|}{ Relative Content (\%) } & \multicolumn{4}{|c|}{$\mathrm{H}_{2}$ Consumption $(\mathrm{mmol} / \mathrm{g})$} \\
\hline & $\alpha_{1}$ & $\alpha_{2}$ & $\beta$ & $\gamma$ & $\alpha_{1}$ & $\alpha_{2}$ & $\beta$ & $\gamma$ & $\alpha_{1}$ & $\alpha_{2}$ & $\beta$ & $\gamma$ \\
\hline $\mathrm{NiO} / \mathrm{SF}-\mathrm{SiO}_{2}$ & 350.7 & 400.0 & 488.1 & - & 32.9 & 40.5 & 26.6 & - & 0.46 & 0.56 & 0.37 & - \\
\hline $\mathrm{NiO} / \mathrm{SF}-\mathrm{SiC}$ & 354.3 & 396.8 & 510.3 & 817.4 & 24.6 & 31.1 & 43.5 & 0.8 & 0.33 & 0.41 & 0.58 & 0.09 \\
\hline
\end{tabular}

The two catalysts were characterized by the X-ray photoelectron spectroscopy (XPS), as illustrated in Figure 6. In Ni/SF-SiO ${ }_{2}$, the Ni 2p3/2 binding energy (BE) of $852.91 \mathrm{eV}$ was related to metallic $\mathrm{Ni}^{0}$, while the Ni 2p3/2 BE $856.78 \mathrm{eV}$ with the satellite peak of $861.02 \mathrm{eV}$ and the $\mathrm{Ni} 2 \mathrm{p} 1 / 2 \mathrm{BE}$ of 870.0 and $879.49 \mathrm{eV}$ were assigned to $\mathrm{Ni}^{2+}$ species, which correspond to the partially oxidized nickel species. Compared with $\mathrm{Ni} / \mathrm{SF}_{-} \mathrm{SiO}_{2}$, the Ni 2p3/2 and 2p1/2 BEs $(857.02,861.50,870.88$ and 879.98 $\mathrm{eV}$, respectively) of $\mathrm{Ni}^{2+}$ species of $\mathrm{Ni} / \mathrm{SF}-\mathrm{SiC}$ was improved. Furthermore, as for $\mathrm{Ni} / \mathrm{SF}^{-\mathrm{SiO}_{2}}$, the spectrum of the Ni 2p3/2 and 2p1/2 shown peaks at 855.24 and $873.26 \mathrm{eV}$, respectively, which could be ascribed to $\mathrm{Ni}^{3+}$ defects species [42,43]. However, the $\mathrm{BE}$ of $\mathrm{Ni}^{3+}$ species $(855.50$ and $873.78 \mathrm{eV}$ ) of $\mathrm{Ni} / \mathrm{SF}-\mathrm{SiC}$ was increased. The numerous $\mathrm{Ni}^{3+}$ in the two catalysts was generated from $\mathrm{Ni}$ and $\mathrm{O}$ vacancies in the process of calcination for forming the $\mathrm{Ni}_{x} \mathrm{O}_{y}$ species. The surfaces of $\mathrm{Ni}^{2+}$ were oxidized to $\mathrm{Ni}^{3+}$ for forming charge neutrality around the $\mathrm{Ni}$ and $\mathrm{O}$ vacancies, and the surface $\mathrm{Ni}^{3+}$ active sites, which may facilitate charge-transfer and enhance $\mathrm{CO}$ and $\mathrm{H}_{2}$ adsorption [42]. It is obvious 
that $\mathrm{Ni}^{2+}$ and $\mathrm{Ni}^{3+}$ species were playing a dominate role in $\mathrm{Ni} / \mathrm{SF}-\mathrm{SiO}_{2}$ and $\mathrm{Ni} / \mathrm{SF}-\mathrm{SiC}$. Compared with $\mathrm{Ni} / \mathrm{SF}_{-} \mathrm{SiO}_{2}(852.91 \mathrm{eV})$, the binding energy of $\mathrm{Ni}^{0}$ in Ni/SF-SiC $(853.43 \mathrm{eV})$ was shifted to a higher binding energy, which is associated to the enhanced metal-support interactions between $\mathrm{Ni}$ and $\mathrm{SF}-\mathrm{SiC}$. From Table 4 , there were about $5.2 \%$ of Ni elements on the Ni/SF-SiC surface, and that of $\mathrm{Ni} / \mathrm{SF}-\mathrm{SiO}_{2}$ was $4.7 \%$, which indicates that $\mathrm{Ni}$ was easily exposed to the surface of Ni/SF-SiC. In addition, the radio of $\mathrm{Ni}^{0} / \mathrm{Ni}$ and $\mathrm{Ni}^{3+} / \mathrm{Ni}$ was about $11.2 \%$ and $31.0 \%$ for $\mathrm{Ni} / \mathrm{SF}-\mathrm{SiC}$, respectively, which was higher than for $\mathrm{Ni} / \mathrm{SF}-\mathrm{SiO}_{2}$ at $11.0 \%$ and $27.0 \%$, demonstrating that the $\mathrm{Ni}$ species of $\mathrm{Ni} / \mathrm{SF}-\mathrm{SiC}$ were easily oxidized due to their good dispersion and smaller Ni nanoparticles, and there were more vacancies in $\mathrm{Ni} / \mathrm{SF}-\mathrm{SiC}$.

In Figure $6 \mathrm{~b}$, the $\mathrm{O} 1 \mathrm{~s}$ spectra of $\mathrm{Ni} / \mathrm{SF}-\mathrm{SiO}_{2}$ and $\mathrm{Ni} / \mathrm{SF}-\mathrm{SiC}$ catalysts could be distinguished into four sub-peaks: The weakly binding energy peaks $\left(\mathrm{O}_{\mathrm{I}}\right.$ and $\left.\mathrm{O}_{\text {II }}\right)$ were related to the surface lattice oxygen and the adsorbed oxygen [44], respectively; the higher binding energy $\left(\mathrm{O}_{\mathrm{III}}\right.$ and $\left.\mathrm{O}_{\mathrm{IV}}\right)$ corresponded to the defects with a low oxygen coordination and the metal-oxygen bonds, respectively [45]. The binding energy of $\mathrm{O} 1 \mathrm{~s}$ of $\mathrm{Ni} / \mathrm{SF}-\mathrm{SiC}$ was higher than $\mathrm{Ni} / \mathrm{SF}^{-\mathrm{SiO}_{2}}$, demonstrating that the stronger metal-support interactions between Ni and SF-SiC [21]. For the catalysts, the presence of $\mathrm{Ni}^{3+}$ and $\mathrm{O}_{\text {III }}$ could further promote the activity of reactive sites in methanation [45]. In Figure 6c, the $\mathrm{Si} 2 \mathrm{p}$ binding energy of $100.7 \mathrm{eV}$ and $103.0 \mathrm{eV}$ were attributed to the $\mathrm{Si}-\mathrm{C}$ and $\mathrm{Si}-\mathrm{O}$ bond in $\mathrm{Ni} / \mathrm{SF}-\mathrm{SiC}$, respectively. There is only an $\mathrm{Si}-\mathrm{O}$ bond in $\mathrm{Ni} / \mathrm{SF}_{-} \mathrm{SiO}_{2}$ [46]. In Figure $6 \mathrm{~d}$, the spectrum $\mathrm{C}$ 1s of Ni/SF-SiC $(282.7,285.0,288.8 \mathrm{eV})$ corresponded to $\mathrm{C}-\mathrm{Si}, \mathrm{C}-\mathrm{C}$ and $\mathrm{C}=\mathrm{O}$, respectively [47].
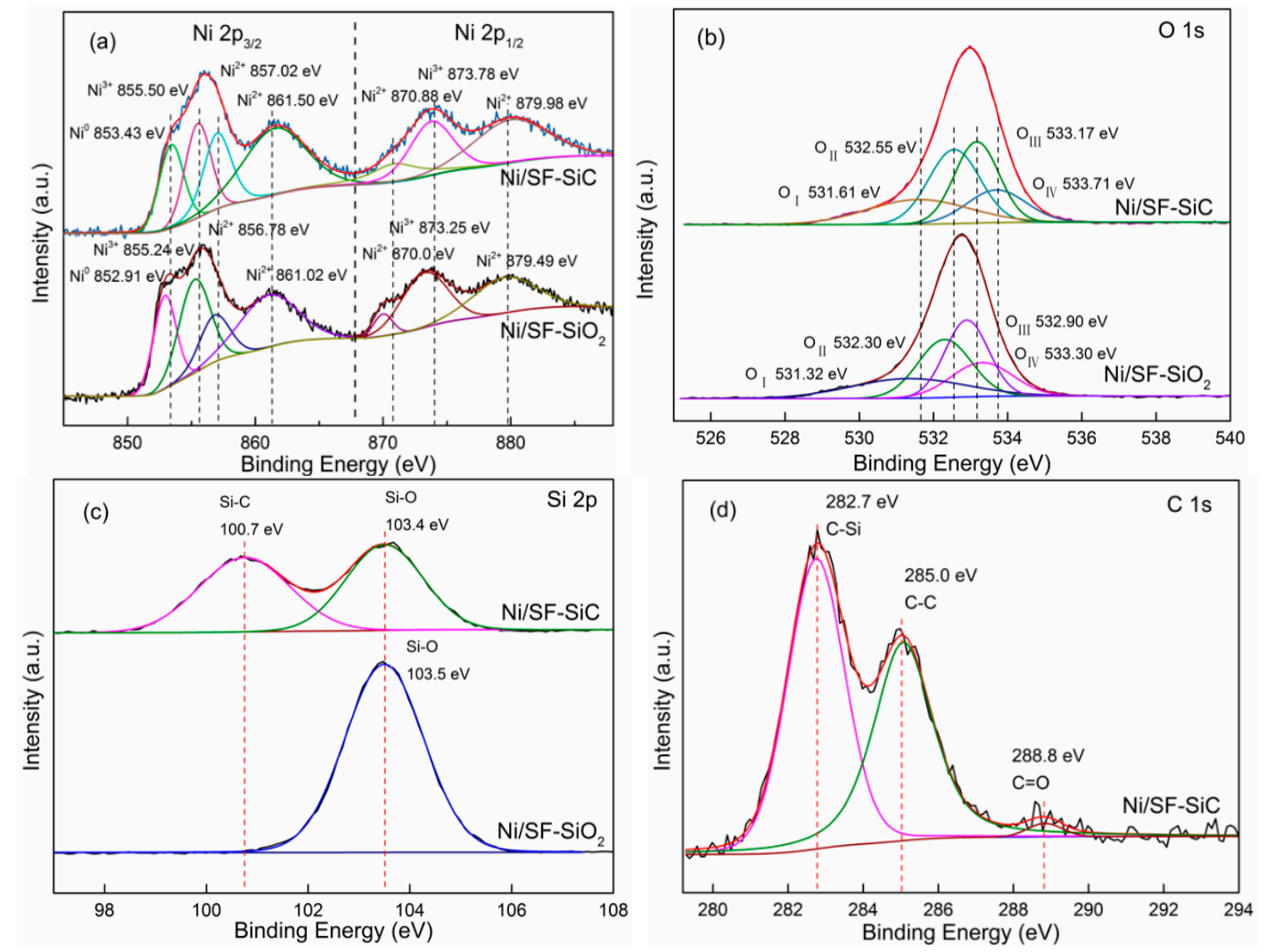

Figure 6. Ni 2p (a), O 1s (b), Si 2p (c) and C 1s (d) XPS spectra of the freshly reduced $\mathrm{Ni} / \mathrm{SF}^{-S_{i O}}$ and $\mathrm{Ni} / \mathrm{SF}-\mathrm{SiC}$.

Table 4. Elemental analysis of $\mathrm{Ni}, \mathrm{O}, \mathrm{Si}$, and C elements content by X-ray photoelectron spectroscopy (XPS).

\begin{tabular}{cccccccc}
\hline Samples & $\mathbf{N i}(\%)$ & $\mathbf{~ N i}^{\mathbf{0}} / \mathbf{N i}(\%)$ & $\mathbf{~ N i}^{2+} / \mathbf{N i}(\%)$ & $\mathbf{~ N i}^{3+} / \mathbf{N i}(\%)$ & $\mathbf{O}(\%)$ & $\mathbf{S i}(\%)$ & $\mathbf{C}(\%)$ \\
\hline $\mathrm{Ni} / \mathrm{SF}-\mathrm{SiO}_{2}$ & 4.7 & 11.0 & 62.0 & 27.0 & 59.7 & 27.1 & 8.6 \\
$\mathrm{Ni} / \mathrm{SF}-\mathrm{SiC}$ & 5.2 & 11.2 & 57.8 & 31.0 & 44.2 & 30.5 & 20.1 \\
\hline
\end{tabular}


The SEM and HRTEM images of the used Ni/SF-SiO 2 and used Ni/SF-SiC catalysts are shown in Figure 7. Compared with the freshly Ni/SF-SiO $2, \mathrm{Ni}$ particles had some agglomeration in the used $\mathrm{Ni} / \mathrm{SF}-\mathrm{SiO}_{2}$ (see Figure 3), and $\mathrm{Ni}$ particles of used $\mathrm{Ni} / \mathrm{SF}-\mathrm{SiO}_{2}$ were larger than fresh $\mathrm{Ni} / \mathrm{SF}-\mathrm{SiO}_{2}$ catalyst for the Ni particles migrated. Furthermore, the migration of Ni particles was caused by the weaker interaction between $\mathrm{Ni}$ species and $\mathrm{SF}-\mathrm{SiO}_{2}$. In contrast, $\mathrm{Ni}$ particles were still keeping good dispersion over the used Ni/SF-SiC, and the mean size of $\mathrm{Ni}$ particles in $\mathrm{u}-\mathrm{Ni} / \mathrm{SF}^{-\mathrm{SiO}_{2}}$ and $\mathrm{u}-\mathrm{Ni} / \mathrm{SF}-\mathrm{SiC}$ was 18.9 and $12.3 \mathrm{~nm}$, respectively. In the $\mathrm{Ni} / \mathrm{SF}-\mathrm{SiO}_{2}$ catalyst, the particles sizes of $\mathrm{Ni}$ species were larger, as compared with the freshly $\mathrm{Ni} / \mathrm{SF}_{-} \mathrm{SiO}_{2}$ (see Table 2). The Ni particles of $\mathrm{Ni} / \mathrm{SF}-\mathrm{SiC}$ catalysts always remained smaller, illustrating the stronger anti-sintering and higher $\mathrm{Ni}$ dispersion characteristics of $\mathrm{Ni} / \mathrm{SF}-\mathrm{SiC}$ than $\mathrm{Ni} / \mathrm{SF}-\mathrm{SiO}_{2}$ [23].
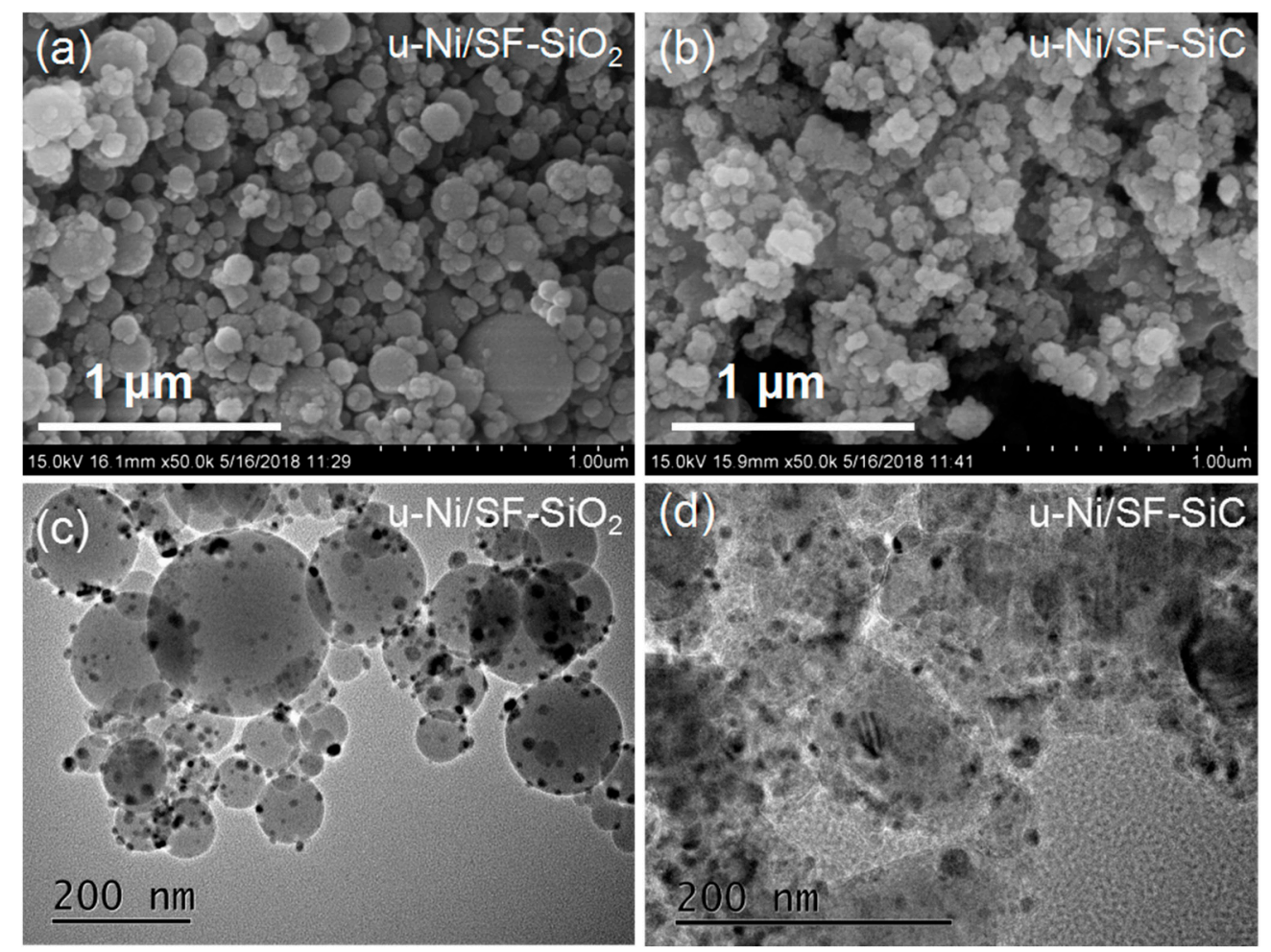

Figure 7. SEM images of the samples: (a) Used Ni/SF-SiO ${ }_{2}$, (b) used Ni/SF-SiC. HRTEM images of (c) used $\mathrm{Ni} / \mathrm{SF}_{-} \mathrm{SiO}_{2}$ and (d) used Ni/SF-SiC.

The Vienna ab initio simulation package (VASP) was employed for the first-principles calculations [48,49]. The generalized gradient approximation was in the Perdew-Burke-Ernzerhof (PBE) form [50]. Chemisorption of $\mathrm{CO}$ and $\mathrm{H}_{2}$ on the surface of catalyst to ensure that the $\mathrm{C}-\mathrm{O}$ and $\mathrm{H}-\mathrm{H}$ bonds were sufficiently activated is the necessary prerequisite to a high-performance methanation catalyst [51]. Therefore, the adsorption of $\mathrm{CO}$ and $\mathrm{H}_{2}$ on Ni- and Nivac-based catalysts was investigated. Two stable adsorption configurations were taken into account, as shown in Figure 8. For the Ni-CO and $\mathrm{Ni}_{\text {vac }}-\mathrm{CO}$ configuration, both two $\mathrm{C}$ atoms interacts with metal atom, forming $\mathrm{C}-\mathrm{Ni}$ bonds (Figure 8a,c). For the $\mathrm{Ni}-\mathrm{H}_{2}$ and $\mathrm{Ni}_{\mathrm{vac}}-\mathrm{H}_{2}$ structure, only one $\mathrm{Ni}$ atom interact with two $\mathrm{H}$ atoms, forming $\mathrm{Ni}-\mathrm{H}$ bonds (Figure $8 b, d$ ). From the above adsorption structure, the calculated binding energy $\left(\mathrm{E}_{\mathrm{b}}\right)$ of $\mathrm{CO}$ and $\mathrm{H}_{2}$ on defect-free $\mathrm{Ni}$ and $\mathrm{Ni}_{\text {vac }}$ are presented in Figure 8. The adsorption energy (absolute value) of $\mathrm{CO}$ and $\mathrm{H}_{2}$ in $\mathrm{Ni}_{\mathrm{vac}}$ was 1.84 and $4.88 \mathrm{eV}$ respectively, which were significantly larger than that of $\mathrm{CO}$ and $\mathrm{H}_{2}$ on defect-free $\mathrm{Ni}$ (1.83 and $4.76 \mathrm{eV}$, respectively.), indicating that the vacancies in the $\mathrm{Ni}$ structure were more favorable for adsorbing $\mathrm{CO}$ and $\mathrm{H}_{2}$ molecules [52,53]. Accordingly, the defect-rich $\mathrm{Ni}$ catalysts were superior to the defect-free $\mathrm{Ni}$ catalysts in the methanation. 


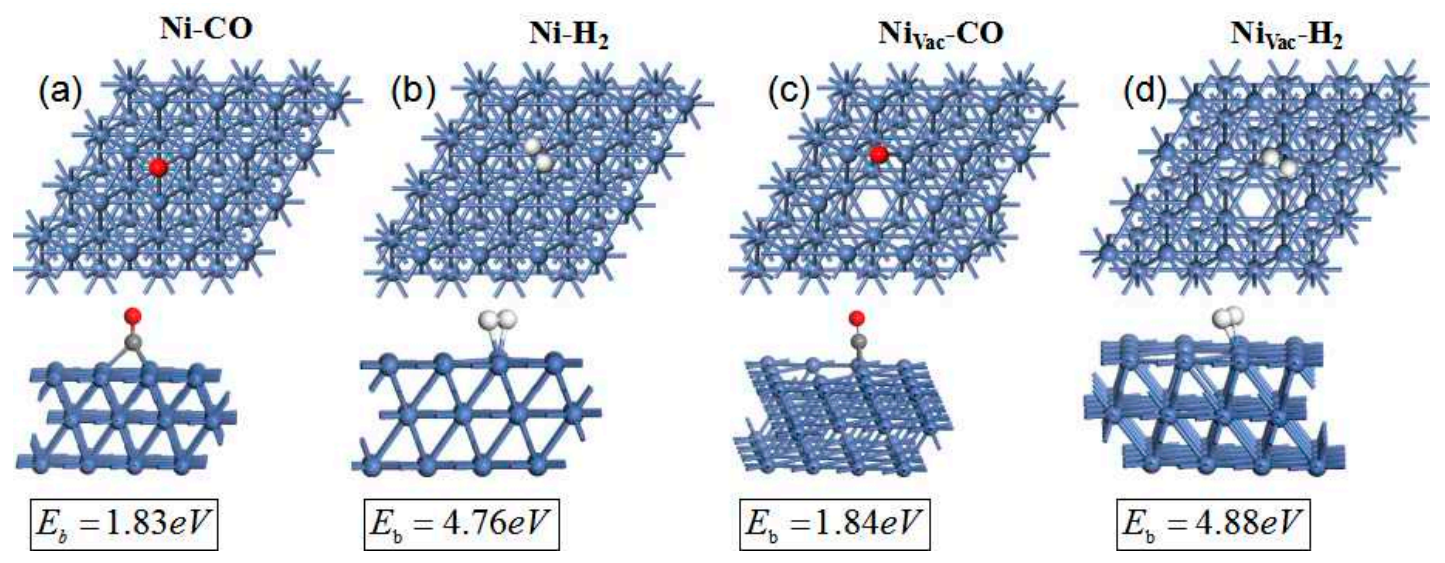

Figure 8. First-principles study of surface $\mathrm{CO}$ and $\mathrm{H}_{2}$ adsorption on different sites. Top and side views of the structures of (a) $\mathrm{Ni}$ and (c) Ni vacancies with $\mathrm{CO}$ adsorption, (b) $\mathrm{Ni}$, (d) Ni vacancies with $\mathrm{H}_{2}$ adsorption. DFT-calculated adsorption energies $\left(\mathrm{E}_{\mathrm{b}}\right)$ of $\mathrm{CO}$ and $\mathrm{H}_{2}$ molecules on the surfaces of $\mathrm{Ni}$ and $\mathrm{Ni}$ vacancies are also presented, respectively. Blue, red, gray and white balls represent the Ni, O, C, and $\mathrm{H}$ atoms, respectively.

\section{Materials and Methods}

\subsection{Preparation of Catalysts}

The details for waste silica fume (Hesheng Silicon Industry Co., Ltd., Xinjiang, China) tested by X-ray fluorescence (XRF) were as follows: (wt \%) $\mathrm{SiO}_{2} 97.55, \mathrm{CaO} 0.81, \mathrm{~K}_{2} \mathrm{O} 0.43, \mathrm{Al}_{2} \mathrm{O}_{3}$ 0.42, $\mathrm{MgO} 0.31$, $\mathrm{SiO}_{3} 0.12, \mathrm{Na}_{2} \mathrm{O} 0.11, \mathrm{Fe}_{2} \mathrm{O}_{3} 0.08, \mathrm{P}_{2} \mathrm{O}_{5} 0.06$, and others 0.11 . The waste silica fume (5 g) was mixed with $1.3 \mathrm{~g}$ of Acetylene black and $6.4 \mathrm{~g} \mathrm{Mg}$ powder with $2.79 \mathrm{~g} \mathrm{NaCl}$ and $3.56 \mathrm{~g} \mathrm{KCl}$, and transferred to a graphite boat. The mixture powders were calcined at a temperature of $1100^{\circ} \mathrm{C}$ for $3 \mathrm{~h}$ in argon atmosphere. The heating rate from room temperature to $700{ }^{\circ} \mathrm{C}$ was $10{ }^{\circ} \mathrm{C} / \mathrm{min}$, and from $700{ }^{\circ} \mathrm{C}$ to $1100{ }^{\circ} \mathrm{C}$ was $5{ }^{\circ} \mathrm{C} / \mathrm{min}$. The resulting solid was exposed to $2 \mathrm{M}$ aqueous $\mathrm{HCl}$ for $3 \mathrm{~h}$ to remove magnesium and magnesium oxide. The solution was subsequently filtered and washed repeatedly with water and then dried in an oven overnight at $100^{\circ} \mathrm{C}$. Additionally, the synthesized samples were heat-treated in air at $700{ }^{\circ} \mathrm{C}$ for $3 \mathrm{~h}$ to remove residual carbon. Moreover, in order to remove unreacted $\mathrm{SiO}_{2}$, the product was immersed in the solution of $\mathrm{NaOH}$ and $\mathrm{HF}$, respectively, and this was followed by washing thoroughly by repeated centrifugation. The final production was SF-SiC.

This work employed impregnation method to synthesize the catalysts: $2 \mathrm{~g}$ SF-SiC nano material was immersed in the aqueous solution of $\mathrm{Ni}\left(\mathrm{NO}_{3}\right)_{2} \cdot 6 \mathrm{H}_{2} \mathrm{O}(1.1235 \mathrm{~g}$, Shanghai Macklin Biochemical Co., Ltd., Shanghai, China, AR, $>98 \%$ ) and stirred for $12 \mathrm{~h}$ at $80^{\circ} \mathrm{C}$, then dried for $12 \mathrm{~h}$ at $80^{\circ} \mathrm{C}$ and calcined at $550{ }^{\circ} \mathrm{C}$ for $3 \mathrm{~h}$ at the rate of $10{ }^{\circ} \mathrm{C} / \mathrm{min}$ [31]. The obtained catalyst was NiO/SF-SiC. The wasted silica fume was prepared into catalyst $\mathrm{NiO} / \mathrm{SF}-\mathrm{SiO}_{2}$ in the same way.

\subsection{Physical Characterization of the Synthesized Samples}

The chemical composition of waste silica fume was analyzed by using X-ray fluorescence (XRF, XRF-1800). The powers were characterized by X-ray diffraction (XRD, Bruker D8 Advance X-ray diffractometer with $\mathrm{Cu}$ Karadiation $(\lambda=1.5406 \AA$ ) operated at $40 \mathrm{kv}$ and $40 \mathrm{~mA}) . \mathrm{H}_{2}$ temperature programmed reduction $\left(\mathrm{H}_{2}\right.$-TPR) was tested by AutoChemII2920 from room temperature to $900{ }^{\circ} \mathrm{C}$ at the rate of $10{ }^{\circ} \mathrm{C} / \mathrm{min}$ with a gas $\left(10\right.$ vol. $\left.\% \mathrm{H}_{2} / \mathrm{Ar}\right)$ flow of $30 \mathrm{~mL} / \mathrm{min}$ at $900{ }^{\circ} \mathrm{C}$. The surface chemical composition was studied by an X-ray photoelectron spectroscopy (XPS) conducted on a Thermo Scientific Escalab 250Xi. The Micromeritics ASAP 2460 BET apparatus was used to measure the Brunauer-Ennett-Teller (BET) specific surface area and Barrett-Joyner-Halenda (BHJ) pore structure of the catalysts. The microscopic feature of the catalysts was researched by field emission scanning electron microscope (SEM) (S-4800, Hitachi, Tokyo, Japan) and transmission electron microscopy (TEM) 
(TecaiG2F20, FEI, 200 kV). Energy dispersed spectroscopy (EDS) (Tecnai G2 F20 S-TWIN (200 KV) was conducted to determine the elemental distribution.

\subsection{CO Methanation Performance Test of Powdered Catalyst}

The reactivity of the catalysts was tested in a fixed bed reactor (Tianjin Tianda Tianrui Petrochemical Equipment Manufacturing Co., Ltd., Tianjin, China.) at atmospheric pressure with a stainless steel tubular microreactor (a $66 \mathrm{~cm}$ long with an inner diameter of $10 \mathrm{~mm}$ ). The $0.217 \mathrm{~g}$ catalyst was placed in the middle of the reaction tube, and before the feed syngas $\mathrm{H}_{2} / \mathrm{CO}$ with a volume ratio of $3: 1$ was introduced to the reactor, the catalyst was reduced in $60 \mathrm{~mL} / \mathrm{min}_{2}$ at $500{ }^{\circ} \mathrm{C}$ for $2 \mathrm{~h}$. Then, the $\mathrm{CO}$ methanation performance tested in the temperature region of $250-550{ }^{\circ} \mathrm{C}$ at intervals of $50^{\circ} \mathrm{C}$, at a synthesis gas (Beijing AP BAIF Gases Industry CO., Ltd., Beijing, China.) flow rate of $65 \mathrm{~mL} / \mathrm{min}$ and a weight space velocity of $18,000 \mathrm{~mL} \cdot \mathrm{g}^{-1} \cdot \mathrm{h}^{-1}$. The composition of effluent gases was analyzed by gas chromatography (GC-2014C, SHIMADZU CO., Ltd., Beijing, China.) with TDX-01 column. We also conducted $50 \mathrm{~h}$ lifetime tests for Ni/SF-SiO ${ }_{2}$ and Ni/VMT-SiC catalysts at $350{ }^{\circ} \mathrm{C}$ with all other parameters adopting the testing values. The $\mathrm{CO}$ conversion, $\mathrm{CH}_{4}$ selectivity and yield are defined as follows:

$$
\begin{aligned}
\text { CO conversion: } \mathrm{X}_{\mathrm{CO}}(\%) & =[\mathrm{CO}]_{\text {in }}-[\mathrm{CO}]_{\text {out }} /[\mathrm{CO}]_{\text {in }} \times 100 \% \\
\mathrm{CH}_{4} \text { selectivity: } \mathrm{S}_{\mathrm{CH} 4}(\%) & =\left[\mathrm{CH}_{4}\right]_{\text {out }} /[\mathrm{CO}]_{\text {in }}-[\mathrm{CO}]_{\text {out }} \times 100 \% \\
\mathrm{CH}_{4} \text { yield: } \mathrm{Y}_{\mathrm{CH} 4} & =\left[\mathrm{CH}_{4}\right]_{\text {out }} /[\mathrm{CO}]_{\text {in }} \times 100 \%
\end{aligned}
$$

Here, $[\mathrm{CO}]_{\text {in }}$ is the moles of $\mathrm{CO}$ in the feed stream, $[\mathrm{CO}]_{\text {out }}$ is the moles of $\mathrm{CO}$ in the effluent gas; $\left[\mathrm{CH}_{4}\right]_{\text {out }}$ is the moles of $\mathrm{CH}_{4}$ in the effluent gas.

\section{Conclusions}

A large quantity of silica fume is deserted in industrial disposal with the development of the metallic silicon industry, which brings about resources wasting, and results in serious pollution by the dust and powder. In this work, silicon carbide ceramics were successfully synthesized using waste silica fume, and we prepared defect-rich $\mathrm{Ni} / \mathrm{SF}-\mathrm{SiO}_{2}$ and $\mathrm{Ni} / \mathrm{SF}-\mathrm{SiC}$ catalysts by conventional impregnation method. The presence of $\mathrm{Ni}$ vacancies enhanced the adsorption energy of $\mathrm{CO}$ and $\mathrm{H}_{2}$, which significantly improved the catalytic performance for methanation. Compared to the $\mathrm{Ni} / \mathrm{SF}-\mathrm{SiO}_{2}$ counterpart, the Ni/SF-SiC catalyst exhibited a higher reactivity and stronger anti-sintering, which could be related to the excellent thermal conductivity of SF-SiC and the good dispersion and stronger metal-support interaction in the Ni/SF-SiC catalyst. Therefore, making full use of the "garbage" generated in the industrial production process, turning waste into treasure, not only achieves the maximum use of resources, but also makes a great contribution to the protection of the environment.

Author Contributions: F.Y., G.G. and J.Z. designed and administered the experiments; Q.S. performed experiments; Q.S., X.Z., J.L., X.R., H.Z., M.Z. and B.D. collected and analyzed data. All authors discussed the data and wrote the manuscript.

Funding: The research was funded by [Major Science and Technology Project of Xinjiang Bingtuan] grant number [2017AA007], [the National Natural Science Foundation of China] grant number [21403144, 11464038, 11764034], [the Program for Changjiang Scholars and Innovative Research Team in University] grant number [IRT_15R46].

Acknowledgments: The work was supported by Major Science and Technology Project of Xinjiang Bingtuan (No. 2017AA007), the National Natural Science Foundation of China (Grant Nos. 21403144, 11464038, 11764034), and the Program for Changjiang Scholars and Innovative Research Team in University (No. IRT_15R46).

Conflicts of Interest: The authors declare no conflict of interest. 


\section{References}

1. Li, Q.; Wang, C.-A.; Tie, S. Synthesis of bamboo-like SiC whiskers from waste silica fume. Cryst. Res. Technol. 2014, 49, 290-297. [CrossRef]

2. Moen, M.; Halvorsen, T.; Mørk, K.; Velken, S. Recycling of silicon metal powder from industrial powder waste streams. Met. Powder Rep. 2017, 72, 182-187. [CrossRef]

3. Zhong, Y.; Shaw, L.L.; Manjarres, M.; Zawrah, M.F. Synthesis of Silicon Carbide Nanopowder Using Silica Fume. J. Am. Ceram. Soc. 2010, 93, 3159-3167. [CrossRef]

4. Danghyan, V.; Novoa, S.C.; Mukasyan, A.; Wolf, E.E. Pressure dilution, a new method to prepare a stable $\mathrm{Ni}$ /fumed silica catalyst for the dry reforming of methane. Appl. Catal. B Environ. 2018, 234, 178-186. [CrossRef]

5. Ji, H.; Huang, Z.; Chen, K.; Li, W.; Gao, Y.; Fang, M.; Liu, Y.G.; Wu, X. Synthesis of $\mathrm{Si}_{3} \mathrm{~N}_{4}$ powder with tunable $\alpha / \beta-\mathrm{Si}_{3} \mathrm{~N}_{4}$ content from waste silica fume using carbothermal reduction nitridation. Powder Technol. 2014, 252, 51-55. [CrossRef]

6. Wang, Y.; Chen, J.; Lei, X.; Ren, Y.; Wu, J. Preparation of high silica microporous zeolite SSZ-13 using solid waste silica fume as silica source. Adv. Powder Technol. 2018, 29, 1112-1118. [CrossRef]

7. Kumar, P.; Mal, N.; Oumi, Y.; Yamana, K.; Sano, T. Mesoporous materials prepared using coal fly ash as the silicon and aluminium source. J. Mater. Chem. 2001, 11, 3285-3290. [CrossRef]

8. Zhang, T.; Hu, L.; Liang, J.; Han, Y.; Lu, Y.; Zhu, Y.; Qian, Y. Porous silicon nano-aggregate from silica fume as an anode for high-energy lithium-ion batteries. RSC Adv. 2016, 6, 30577-30581. [CrossRef]

9. Li, P.; Zhu, M.; Tian, Z.; Han, Y.; Zhang, Y.; Zhou, T.; Kang, L.; Dan, J.; Guo, X.; Yu, F.; et al. Two-Dimensional Layered Double Hydroxide Derived from Vermiculite Waste Water Supported Highly Dispersed Ni Nanoparticles for CO Methanation. Catalysts 2017, 7, 79. [CrossRef]

10. Li, P.; Yu, F.; Altaf, N.; Zhu, M.; Li, J.; Dai, B.; Wang, Q. Two-Dimensional Layered Double Hydroxides for Reactions of Methanation and Methane Reforming in C1 Chemistry. Materials 2018, 11, 221. [CrossRef]

11. Liu, Q.; Qiao, Y.; Tian, Y.; Gu, F.; Zhong, Z.; Su, F. Ordered Mesoporous Ni-Fe-Al Catalysts for CO Methanation with Enhanced Activity and Resistance to Deactivation. Ind. Eng. Chem. Res. 2017, 56, 9809-9820. [CrossRef]

12. Bian, Z.; Xin, Z.; Meng, X.; Tao, M.; Lv, Y.; Gu, J. Effect of Citric Acid on the Synthesis of CO Methanation Catalysts with High Activity and Excellent Stability. Ind. Eng. Chem. Res. 2017, 56, 2383-2392. [CrossRef]

13. Zhang, M.; Li, P.; Zhu, M.; Tian, Z.; Dan, J.; Li, J.; Dai, B.; Yu, F. Ultralow-weight loading Ni catalyst supported on two-dimensional vermiculite for carbon monoxide methanation. Chin. J. Chem. Eng. 2018, 26, 1873-1878. [CrossRef]

14. Tan, C.; Liu, J.; Zhang, H.; Wang, J.; Li, S.; Song, J.; Zhang, Y.; Zhang, S. Low temperature synthesis of 2H-SiC powders via molten-salt-mediated magnesiothermic reduction. Ceram. Int. 2017, 43, 2431-2437. [CrossRef]

15. Gao, P.-C.; Lei, Y.; Pérez, A.F.; Rajoua, K.; Zitoun, D.; Favier, F. New topotactic synthetic route to mesoporous silicon carbide. J. Mater. Chem. 2011, 21, 15798-15805. [CrossRef]

16. Wang, H.; Gao, S.; Peng, S.; Zhou, X.; Zhang, H.; Zhou, X.; Li, B. KD-S SiCf/SiC composites with BN interface fabricated by polymer infiltration and pyrolysis process. J. Adv. Ceram. 2018, 7, 169-177. [CrossRef]

17. Ma, Q.; Cai, L. Fabrication and oxidation resistance of mullite/yttrium silicate multilayer coatings on C/SiC composites. J. Adv. Ceram. 2017, 6, 360-367. [CrossRef]

18. Magnani, G.; Galvagno, S.; Sico, G.; Portofino, S.; Freda, C.; Burresi, E. Sintering and mechanical properties of $\beta$-SiC powder obtained from waste tires. J. Adv. Ceram. 2016, 5, 40-46. [CrossRef]

19. Fu, C.; Yang, Y.; Huang, Z.; Liu, G.; Zhang, H.; Jiang, F.; Wei, Y.; Jiao, Z. Investigation on the laser ablation of $\mathrm{SiC}$ ceramics using micro-Raman mapping technique. J. Adv. Ceram. 2016, 5, 253-261. [CrossRef]

20. Zhang, G.; Peng, J.; Sun, T.; Wang, S. Effects of the oxidation extent of the SiC surface on the performance of $\mathrm{Ni} / \mathrm{SiC}$ methanation catalysts. Chin. J. Catal. 2013, 34, 1745-1755. [CrossRef]

21. Jin, G.; Gu, F.; Liu, Q.; Wang, X.; Jia, L.; Xu, G.; Zhong, Z.; Su, F. Highly stable Ni/SiC catalyst modified by $\mathrm{Al}_{2} \mathrm{O}_{3}$ for $\mathrm{CO}$ methanation reaction. RSC Adv. 2016, 6, 9631-9639. [CrossRef]

22. Yu, Y.; Jin, G.-Q.; Wang, Y.-Y.; Guo, X.-Y. Synthetic natural gas from CO hydrogenation over silicon carbide supported nickel catalysts. Fuel Process. Technol. 2011, 92, 2293-2298. [CrossRef]

23. Li, J.; Zhu, Q.; Peng, W.; Zhang, Q.; Luo, G.; Wei, F. Novel hierarchical Ni/MgO catalyst for highly efficient CO methanation in a fluidized bed reactor. AIChE J. 2017, 63, 2141-2152. [CrossRef] 
24. Zhao, A.; Ying, W.; Zhang, H.; Ma, H.; Fang, D. Ni- $\mathrm{Al}_{2} \mathrm{O}_{3}$ catalysts prepared by solution combustion method for syngas methanation. Catal. Commun. 2012, 17, 34-38. [CrossRef]

25. Chen, D.; Christensen, K.; Ochoafernandez, E.; Yu, Z.; Totdal, B.; Latorre, N.; Monzon, A.; Holmen, A. Synthesis of carbon nanofibers: Effects of Ni crystal size during methane decomposition. J. Catal. 2005, 229, 82-96. [CrossRef]

26. Zhang, G.; Sun, T.; Peng, J.; Wang, S.; Wang, S. A comparison of $\mathrm{Ni} / \mathrm{SiC}$ and $\mathrm{Ni} / \mathrm{Al}_{2} \mathrm{O}_{3}$ catalyzed total methanation for production of synthetic natural gas. Appl. Catal. A Gen. 2013, 462-463, 75-81. [CrossRef]

27. Liu, Q.H.; Dong, X.F.; Lin, W.M. Highly selective $\mathrm{CO}$ methanation over amorphous Ni-Ru-B/ $\mathrm{ZrO}_{2}$ catalyst. Chin. Chem. Lett. 2009, 20, 889-892. [CrossRef]

28. Liu, S.-S.; Jin, Y.-Y.; Han, Y.; Zhao, J.; Ren, J. Highly stable and coking resistant Ce promoted Ni/SiC catalyst towards high temperature CO methanation. Fuel Process. Technol. 2018, 177, 266-274. [CrossRef]

29. Zhao, B.; Chen, Z.; Chen, Y.; Ma, X. Syngas methanation over $\mathrm{Ni} / \mathrm{SiO}_{2}$ catalyst prepared by ammonia-assisted impregnation. Int. J. Hydrogen Energy 2017, 42, 27073-27083. [CrossRef]

30. Tao, M.; Meng, X.; Lv, Y.; Bian, Z.; Xin, Z. Effect of impregnation solvent on Ni dispersion and catalytic properties of Ni/SBA-15 for CO methanation reaction. Fuel 2016, 165, 289-297. [CrossRef]

31. Li, P.; Zhu, M.; Dan, J.; Kang, L.; Lai, L.; Cai, X.; Zhang, J.; Yu, F.; Tian, Z.; Dai, B. Two-dimensional porous $\mathrm{SiO}_{2}$ nanomesh supported high dispersed Ni nanoparticles for $\mathrm{CO}$ methanation. Chem. Eng. J. 2017, 326, 774-780. [CrossRef]

32. Gao, J.; Jia, C.; Li, J.; Zhang, M.; Gu, F.; Xu, G.; Zhong, Z.; Su, F. Ni/ $\mathrm{Al}_{2} \mathrm{O}_{3}$ catalysts for $\mathrm{CO}$ methanation: Effect of $\mathrm{Al}_{2} \mathrm{O}_{3}$ supports calcined at different temperatures. J. Energy Chem. 2013, 22, 919-927. [CrossRef]

33. Li, P.; Wen, B.; Yu, F.; Zhu, M.; Guo, X.; Han, Y.; Kang, L.; Huang, X.; Dan, J.; Ouyang, F.; et al. High efficient nickel/vermiculite catalyst prepared via microwave irradiation-assisted synthesis for carbon monoxide methanation. Fuel 2016, 171, 263-269. [CrossRef]

34. Yu, Y.; Jin, G.; Wang, Y.; Guo, X. Synthesis of natural gas from CO methanation over SiC supported Ni-Co bimetallic catalysts. Catal. Commun. 2013, 31, 5-10. [CrossRef]

35. Yan, X.; Yuan, C.; Bao, J.; Li, S.; Qi, D.; Wang, Q.; Zhao, B.; Hu, T.; Fan, L.; Fan, B. Ni-based catalyst with enhanced Ni-support interaction for highly efficient CO methanation. Catal. Sci. Technol. 2018, 8, 3474-3483. [CrossRef]

36. Xie, J.; Zhang, H.; Li, S.; Wang, R.; Sun, X.; Zhou, M.; Zhou, J.; Lou, X.W.; Xie, Y. Defect-rich MoS 2 ultrathin nanosheets with additional active edge sites for enhanced electrocatalytic hydrogen evolution. Adv. Mater. 2013, 25, 5807-5813. [CrossRef] [PubMed]

37. Chen, X.; Jin, J.; Sha, G.; Li, C.; Zhang, B.; Su, D.; Williams, C.T.; Liang, C. Silicon-nickel intermetallic compounds supported on silica as a highly efficient catalyst for CO methanation. Catal. Sci. Technol. 2014, 4, 53-61. [CrossRef]

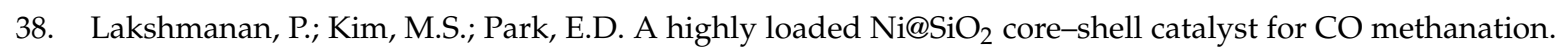
Appl. Catal. A Gen. 2016, 513, 98-105. [CrossRef]

39. Zhang, M.; Li, P.; Tian, Z.; Zhu, M.; Wang, F.; Li, J.; Dai, B.; Yu, F.; Qiu, H.; Gao, H. Clarification of Active Sites at Interfaces between Silica Support and Nickel Active Components for Carbon Monoxide Methanation. Catalysts 2018, 8, 293. [CrossRef]

40. Cai, W.-J.; Qian, L.-P.; Yue, B.; He, H.-Y. Rh doping effect on coking resistance of Ni/SBA-15 catalysts in dry reforming of methane. Chin. Chem. Lett. 2014, 25, 1411-1415. [CrossRef]

41. García-Vargas, J.M.; Valverde, J.L.; de Lucas-Consuegra, A.; Gómez-Monedero, B.; Sánchez, P.; Dorado, F. Precursor influence and catalytic behaviour of $\mathrm{Ni} / \mathrm{CeO}_{2}$ and $\mathrm{Ni} / \mathrm{SiC}$ catalysts for the tri-reforming process. Appl. Catal. A Gen. 2012, 431-432, 49-56.

42. Zhao, Y.; Jia, X.; Chen, G.; Shang, L.; Waterhouse, G.I.; Wu, L.Z.; Tung, C.H.; O'Hare, D.; Zhang, T. Ultrafine $\mathrm{NiO}$ Nanosheets Stabilized by $\mathrm{TiO}_{2}$ from Monolayer NiTi-LDH Precursors: An Active Water Oxidation Electrocatalyst. J. Am. Chem. Soc. 2016, 138, 6517-6524. [CrossRef]

43. Sasi, B.; Gopchandran, K.G. Nanostructured mesoporous nickel oxide thin films. Nanotechnology 2007, 18, 115613. [CrossRef]

44. Zhang, M.; Yu, F.; Li, J.; Chen, K.; Yao, Y.; Li, P.; Zhu, M.; Shi, Y.; Wang, Q.; Guo, X. High CO Methanation Performance of Two-Dimensional Ni/MgAl Layered Double Oxide with Enhanced Oxygen Vacancies via Flash Nanoprecipitation. Catalysts 2018, 8, 363. [CrossRef] 
45. Wang, Y.; Xie, C.; Zhang, Z.; Liu, D.; Chen, R.; Wang, S. In Situ Exfoliated, N-Doped, and Edge-Rich Ultrathin Layered Double Hydroxides Nanosheets for Oxygen Evolution Reaction. Adv. Funct. Mater. 2018, 28, 1703363. [CrossRef]

46. Adhikari, S.; Eswar, N.K.; Sangita, S.; Sarkar, D.; Madras, G. Investigation of nano Ag-decorated SiC particles for photoelectrocatalytic dye degradation and bacterial inactivation. J. Photochem. Photobiol. A Chem. 2018, 357, 118-131. [CrossRef]

47. Hao, J.-Y.; Wang, Y.-Y.; Tong, X.-L.; Jin, G.-Q.; Guo, X.-Y. Photocatalytic hydrogen production over modified $\mathrm{SiC}$ nanowires under visible light irradiation. Int. J. Hydrogen Energy 2012, 37, 15038-15044. [CrossRef]

48. Kresse, G.; Furthmüller, J. Efficient iterative schemes for ab initio total-energy calculations using a plane-wave basis set. Phys. Rev. B Condens. Matter 1996, 54, 11169-11186. [CrossRef]

49. Kresse, G.; Furthmüller, J. Efficiency of ab-initio total energy calculations for metals and semiconductors using a plane-wave basis set. Comp. Mater. Sci. 1996, 6, 15-50. [CrossRef]

50. Perdew, J.P.; Burke, K.; Ernzerhof, M. Generalized Gradient Approximation Made Simple. Phys. Rev. Lett. 1998, 77, 3865-3868. [CrossRef]

51. Ling, C.; Bai, X.; Ouyang, Y.; Du, A.; Wang, J. Single Molybdenum Atom Anchored on N-Doped Carbon as a Promising Electrocatalyst for Nitrogen Reduction into Ammonia at Ambient Conditions. J. Phys. Chem. C 2018, 122, 16842-16847. [CrossRef]

52. Liu, Y.; Cheng, H.; Lyu, M.; Fan, S.; Liu, Q.; Zhang, W.; Zhi, Y.; Wang, C.; Xiao, C.; Wei, S.; et al. Low overpotential in vacancy-rich ultrathin $\mathrm{CoSe}_{2}$ nanosheets for water oxidation. J. Am. Chem. Soc. 2014, 136, 15670-15675. [CrossRef] [PubMed]

53. Yan, D.; Li, Y.; Huo, J.; Chen, R.; Dai, L.; Wang, S. Defect Chemistry of Nonprecious-Metal Electrocatalysts for Oxygen Reactions. Adv. Mater. 2017, 29, 1606459. [CrossRef] [PubMed]

(C) 2019 by the authors. Licensee MDPI, Basel, Switzerland. This article is an open access article distributed under the terms and conditions of the Creative Commons Attribution (CC BY) license (http:/ / creativecommons.org/licenses/by/4.0/). 